\title{
Supply Chain Management Model to Improve the Competitiveness of SMEs in the ASEAN Economic Community Era 2015-2025 in Tanjung Jabung Barat Regency, Indonesia
}

\author{
Fitriaty, Shofia Amin, and Idham Khalik
}

Corresponding Author:

Fitriaty

fitriaty@unja.ac.id

Received: 29 January 2019

Accepted: 27 February 2019

Published: 24 March 2019

Publishing services provided by

Knowledge E

(c) Fitriaty et al. This article is

distributed under the terms of

the Creative Commons

Attribution License, which

permits unrestricted use and

redistribution provided that the

original author and source are

credited.

Selection and Peer-review under the responsibility of the 3rd ICEEBA Conference Committee.

\section{Abstract}

Creative industry is one of the economic sectors that is able to contribute directly to employment and to increase household income. In its journey, the creative industry is often difficult to grow well and has competitiveness even though it has good potential supported by the logistic of available raw materials that are the result of the natural resources of the local area. Furthermore, globalization and economic development is a process to create a single market in which logistics is an important tool in achieving competitive advantage by improving the quality of supply chain management as a facility to improve competitive advantage, especially in the era of ASEAN Economic Community (AEC). Supply chain management will improve innovation and other business approaches to provide positive results by improving service quality by reducing costs and efficiency of process and time. Hence, this study covered the development strategy of MSMEs in marine areas that have their own resources to be more competitive and become superior to the Indonesian market.

Keywords: strategy, competitiveness, MSMEs, supply chain

\section{Introduction}

The ASEAN Economic Community (AEC) was legalized on December31, 2015, where ASEAN's single market was formed by integrating the ASEAN economy with four pillars; creating a single market and production base, increasing competitiveness, promoting equitable economic development, and integrating ASEAN into global economy. The enactment of the ASEAN Economic Community provides a great opportunity because of the free flow of goods, services, investment, capital, and skilled labor, and encourages the formation of integration in the Southeast Asia region to be more able to compete dynamically in the face of trade competition in the global region. Intra ASEAN trade 
reaches USD 1.5 trillion per year with a combination of gross domestic product closed to USD 2.5 trillion with a combined population of 630 million people. This liberalization will present many opportunities and challenges and requires readiness for businesses to deal with it as a free trade area. The impact is that there will be $70 \%$ of products made in ASEAN countries will not be subject to tariffs. As a result of this tariff relief, the movement of raw material prices has decreased by $20 \%$. However, this condition has not been widely used by MSMEs, only around $20-25 \%$ of Indonesian companies are utilizing the decrease in preferential rates applying in the AEC.

The development of MSMEs is an integrated part of economic integration among ASEAN member countries. Various collaborative initiatives to improve the performance of MSMEs are carried out. In general, Indonesia's MSME performance is still relatively low compared to countries with relatively similar levels of development, especially in terms of productivity, contribution to exports, participation in global and regional production networks, and contributions to added value. Some studies showed that the ability of MSMEs to compete in the global era depends on several things; internal factors such as business scale, personality stakeholders, educational background and corporate culture that can be reflected in the level of productivity and innovation of the company, and external factors outside the company such as access to capital and policy environment associated with MSMEs which use more social welfare approaches than business approaches. (Bank Indonesia, 2015, 2016).

The creative industry has a significant role in contributing to national economic growth. Developments in Indonesia contribute significantly to the economy and employment. Based on statistics from the Ministry of Tourism and Creative Economy in 20102013 , the contribution of creative industries to GDP was $7.1 \%$, the total export value was $6.1 \%$, and the absorption of labor was $10,7 \%$. Overall, creative industry growth was $5.6 \%$ and the handicraft sector that has the highest growth rate was fashion and culinary when compared to other sectors such as advertising, architecture, art markets, design, photographic video films, and others.

Tanjung Jabung Barat Regency has a Gross Regional Domestic Product that increased significantly from 2015 amounting from 29,418,506.10 (million) to 31,443,365 65.82 (million) in 2016 with total exports of goods and services amounting to 25,591,273.10 million and increased to 27,305,595.55 million in 2016. The national average is still under the target while has shown an increase from year to year. Micro, Small and Medium Enterprises (MSMEs) also experienced an increase resulting in absorption of workers. 
Supply Chain Management is a comprehensive demand related to sources, purchase of raw materials, administrative processes and networks that consist of all parties directly or indirectly related. This includes the business itself, suppliers, sellers, partners and so on in producing and distributing goods and services to final partners at the upstream and downstream levels (Thoo et al., 2012). Supply Chain Management will develop well if it integrates between suppliers, production processes, and partners to achieve good performance and overcome the problems faced by MSMEs in the development of their business, hence some of the problems and strategic issues related to MSMEs can be resolved properly such as; 1 ) availability of professional and competitive creative resources, 2) availability of quality, diverse, competitive natural resources, and cultural resources that can be accessed easily, 3) creative industries that are competitive, growing, and diverse, 4) availability of appropriate, accessible, and competitive financing, 5) marketing expansion for creative works, 6) availability of appropriate and competitive infrastructure and technology, and 7) institutions that support the development of creative economy along with overall economic growth in Jambi Province and the impact on national economic growth.

\section{Conceptual Framework and Literature Reviews}

\subsection{Definition of small- and medium-sized enterprises (MSME's)}

MSMEs are different from companies in general, this designation lies in the form, scope, and amount of capital that they have. Definition of MSMEs in the context of Indonesian laws and regulations, in Law Number 20 of 2008 concerning Micro, Small and Medium Enterprises, is defined as follows.

TABLE 1: Classification of Micro, Small and Medium Enterprises in Indonesia(Rupiah/and in USD exchange rate 14.000$)$

\begin{tabular}{l|l|l} 
& Total of Wealth & Sales Result/year \\
Micro Enterprises & IDR 50 millions/USD & IDR 300 millions/USD \\
& 3.571 & 21.429 \\
Small Enterprises & IDR $50<x \leq 500$ million & IDR 300 millions $<x \leq 2.5$ \\
& IUSD $3.571<x \leq 35.714$ & Milyard/USD $3.571<x \leq$ \\
Medium Enterprises & IDR 500 millions $<x \leq 10$ & IDR 2,5 Milyard $<x \leq 50$ \\
& Milyard/USD $35.714<x \leq$ & M/IDR $178.571<x \leq$ \\
& 714.285 & 3.571 .428
\end{tabular}

When compared with other companies, MSMEs have a simpler structure and a shorter management level, this makes organizational culture and patterns easier to change (Gourova, 2010). Hence, this convenience makes communication between lines easier 
so that between owners and employees can more unite between perception and strategy at each level in improving business performance. This organizational system can also facilitate improvements from the implementation of Supply Chain Management.

\subsection{Supply chain management (SCM)}

Supply Chain Management is the coordination of a strategic system of traditional business functions and tactics throughout business functions within a given company and throughout a company in the supply chain for the purpose of improving the long-term performance of individual companies and supply chains as a whole (Mentzer et al., 2001). Another understanding of supply chain management supply chain strategies that require the totality of relationships in the chain that works together efficiently to create customer satisfaction at the end. As a consequence, costs must be lowered and focus attention on added value. Supply chain management is a system between business functions in an organization that plays a role in managing tasks related to meeting customer needs ranging from the supply of raw materials to the delivery of goods to customers. The main focus of Supply Chain Management is to provide quality goods to the right customers matching their needs at a low cost, in a shorter time, good quality, and the right amount (Basher, 2010).

\subsection{Competitiveness}

Competitiveness can be defined as the ability to provide products and services as more effective and efficient than relevant competitors. In the trade sector, this means sustainable success in the international market without protection or subsidies. Although transportation costs allow companies from a country to successfully compete in their home markets or in adjacent markets, competitiveness usually refers to the benefits gained through superior productivity. Measures of competitiveness in the trade sector include the profitability of the company, the export yield of the company (export or foreign sales divided by output), and regional or global marketing share. In the trade sector, performance on the international market provides a direct measure of competitiveness. In sectors that are not traded, competitiveness is the ability to adjust or defeat the best companies in the world in terms of costs and quality of goods or services. Measures of competitiveness in the non-trade sector are often difficult, because there is no direct market performance test. Measures of competitiveness in this part of the economy include product quality, profitability, and cost and quality measures. In the 
competitiveness of $A E C$ refers to, how much this product can compete, be productive and efficient production and financial return to increase the size of the company or organization.

\section{Methods}

This study used a combination research method, which is a combination of qualitative and quantitative research methods. The type of combination research used was sequential exploratory design, which at the initial stage of the study used qualitative methods and the next stage used quantitative methods, using secondary data obtained from the Industry and Trade Office of Jambi Province and Tanjung Jabung Barat Regency, Cooperatives and the MSMEs Services of Jambi Province and Tanjung Jabung Barat Regency, the Central Statistics Agency of Jambi Province and Tanjung Jabung Barat Regency, as well as literature studies. Then the primary data was obtained directly from the field survey to the MSMEs actors, the centers of creative economic activities of the community, interviews of experts and stakeholders related to the models and strategies of the creative economy of UMKM in improving competitiveness and supply chain management in Tanjung Jabung Barat Regency. There were 100 AECs as the respondents. The results of this study produced four supply chain models which would then be tested so that they will obtain the supply chain management model goodness of fit using the Analysis Process Hierarchy (AHP). This method can explain a complex and unstructured situation by; 1) dividing into parts, 2) rearranging the parts (or variables) into hierarchy, 3) determining a numerical value for each of these variables through justification in determining the level of importance, and last 4) synthesizing to determine which variables have the highest priority that must be carried out to obtain the expected outcome.

\section{Results and Discussions}

\subsection{Results}

\subsubsection{Pairwise comparison matrix for criteria}

At this stage, an assessment of pairwise comparisons is made between one criterion and others. 
TABLE 2: Paired matrix of MSME criteria.

\begin{tabular}{|l|c|c|c|c|} 
& Raw material & Factory & Distributor & Customer \\
\hline Raw material & 1 & 3.87 & 5.48 & 5.48 \\
\hline Factory & 0.26 & 1 & 3.46 & 3.46 \\
\hline Distributor & 0.18 & 0.29 & 1 & 1.73 \\
\hline Customer & 0.18 & 0.29 & 0.58 & 1 \\
\hline
\end{tabular}

The 1.00 number in the column and row (diagonal) represented the same level of importance between raw materials. While the number 5 in the row of the raw material of the factory column showed that the raw material was more important than the factory. The number 0.2 in the raw material column of the factory row was the result of the calculation of $1 /$ value in the column of raw material in the factory column. (1/5) The other numbers were obtained in the same way.

TABLE 3: Sub-criteria paired matrix for raw materials.

\begin{tabular}{|c|c|c|c|c|c|c|c|c|}
\hline & 1 & 2 & 3 & 4 & 5 & 6 & 7 \\
\hline 1 & 1 & 5.48 & 1.73 & 3.87 & 3.00 & 3.87 & 5.00 \\
\hline 2 & 0.18 & 1 & 1.00 & 3.46 & 5.00 & 3.16 & 5.00 \\
\hline 3 & 0.58 & 1.00 & 1 & 5.00 & 4.47 & 5.00 & 3.87 \\
\hline 4 & 0.26 & 0.29 & 0.20 & 1 & 1.41 & 1.41 & 1.00 \\
\hline 5 & 0.33 & 0.20 & 0.22 & 0.71 & 1 & 1.41 & 1.41 \\
\hline 6 & 0.26 & 0.32 & 0.20 & 0.71 & 0.71 & 1 & 1.00 \\
\hline 7 & 0.20 & 0.20 & 0.26 & 1.00 & 0.71 & 1.00 & 1
\end{tabular}

Note: 1 = Ease of Raw materials; 2 = Price of Raw Materials; 3 = Quality of Raw Materials; 4 = Delivery Time of Raw Materials; 5 = Compliance; 6 Supplier cooperation; and $7=$ Transportation of raw materials.

TABLE 4: Sub-criteria paired matrix for factory.

\begin{tabular}{|l|c|c|c|c|c|c|c|}
\hline & 1 & 2 & 3 & 4 & 5 & 6 & 7 \\
\hline 1 & 1 & 1.00 & 1.00 & 3.87 & 3.46 & 3.87 & 3.46 \\
\hline 2 & 1.00 & 1 & 1.00 & 2.24 & 3.87 & 3.46 & 3.87 \\
\hline 3 & 1.00 & 1.00 & 1 & 5.00 & 5.00 & 5.00 & 5.00 \\
\hline 4 & 0.26 & 0.45 & 0.20 & 1 & 2.00 & 2.00 & 2.00 \\
\hline 5 & 0.29 & 0.26 & 0.20 & 0.50 & 1 & 2.00 & 2.00 \\
\hline 6 & 0.26 & 0.29 & 0.20 & 0.50 & 0.50 & 1 & 1.00 \\
\hline 7 & 0.29 & 0.26 & 0.20 & 0.50 & 0.50 & 1.00 & 1 \\
\hline
\end{tabular}

Note: 1 = Completeness; 2 = Production Costs; 3 = Quality of Production; 4 = Time; 5 = Labor; 6 = Government Assistance; and 7 = Cooperation of SMEs. 
TABLE 5: Sub-criteria paired matrix for distributor.

\begin{tabular}{|c|c|c|c|c|c|c|}
\hline & 1 & 2 & 3 & 4 & 5 & 6 \\
\hline 1 & 1 & 1.73 & 1.73 & 1.00 & 1.00 & 3.46 \\
\hline 2 & 0.58 & 1 & 3.87 & 3.87 & 1.73 & 1.73 \\
\hline 3 & 0.58 & 0.26 & 1 & 1.73 & 1.00 & 1.00 \\
\hline 4 & 1.00 & 0.26 & 0.58 & 1 & 1.41 & 4.47 \\
\hline 5 & 1.00 & 0.58 & 1.00 & 0.71 & 1 & 3.16 \\
\hline 6 & 0.29 & 0.58 & 1.00 & 0.22 & 0.32 & 1 \\
\hline
\end{tabular}

TABLE 6: Sub-criteria paired matrix for customer.

\begin{tabular}{|c|c|c|c|c|c|c|c|c|c|c|}
\hline & 1 & 2 & 3 & 4 & 5 & 6 & 7 & 8 & 9 & \\
\hline 1 & 1 & 1.73 & 1.41 & 1.41 & 1.41 & 1.00 & 1.00 & 1.41 & 1.00 & 1.00 \\
\hline 2 & 0.58 & 1 & 1.73 & 2.24 & 2.24 & 1.73 & 1.00 & 1.73 & 1.73 & 3.87 \\
\hline 3 & 0.71 & 0.58 & 1 & 2.24 & 5.00 & 2.45 & 3.87 & 5.00 & 1.73 & 5.48 \\
\hline 4 & 0.71 & 0.45 & 0.45 & 1 & 4.47 & 2.24 & 2.24 & 3.87 & 2.24 & 3.87 \\
\hline 5 & 0.71 & 0.45 & 0.20 & 0.22 & 1 & 1.00 & 1.00 & 2.24 & 1.00 & 2.24 \\
\hline 6 & 1.00 & 0.58 & 0.41 & 0.45 & 1.00 & 1 & 1.73 & 3.00 & 3.00 & 3.00 \\
\hline 7 & 1.00 & 1.00 & 0.26 & 0.45 & 1.00 & 0.58 & 1 & 2.00 & 2.00 & 2.00 \\
\hline 8 & 0.71 & 0.58 & 0.20 & 0.26 & 0.45 & 0.33 & 0.50 & 1 & 1.00 & 5.00 \\
\hline 9 & 1.00 & 0.58 & 0.58 & 0.45 & 1.00 & 0.33 & 0.50 & 1.00 & 1 & 5.00 \\
\hline 10 & 1.00 & 0.26 & 0.18 & 0.26 & 0.45 & 0.33 & 0.50 & 0.20 & 0.20 & 1 \\
\hline
\end{tabular}

Note: 1 = Online ordering; 2 = Speed of fulfillment; 3 = Product quality standards; 4 = Payment; 5 = Customer partners; 6 = Halal certificate; 7 = BPOM certificate; 8 = Brand; $9=$ Customer satisfaction; and $10=$ Feedback. 


\subsubsection{Value chart (weight) criteria}

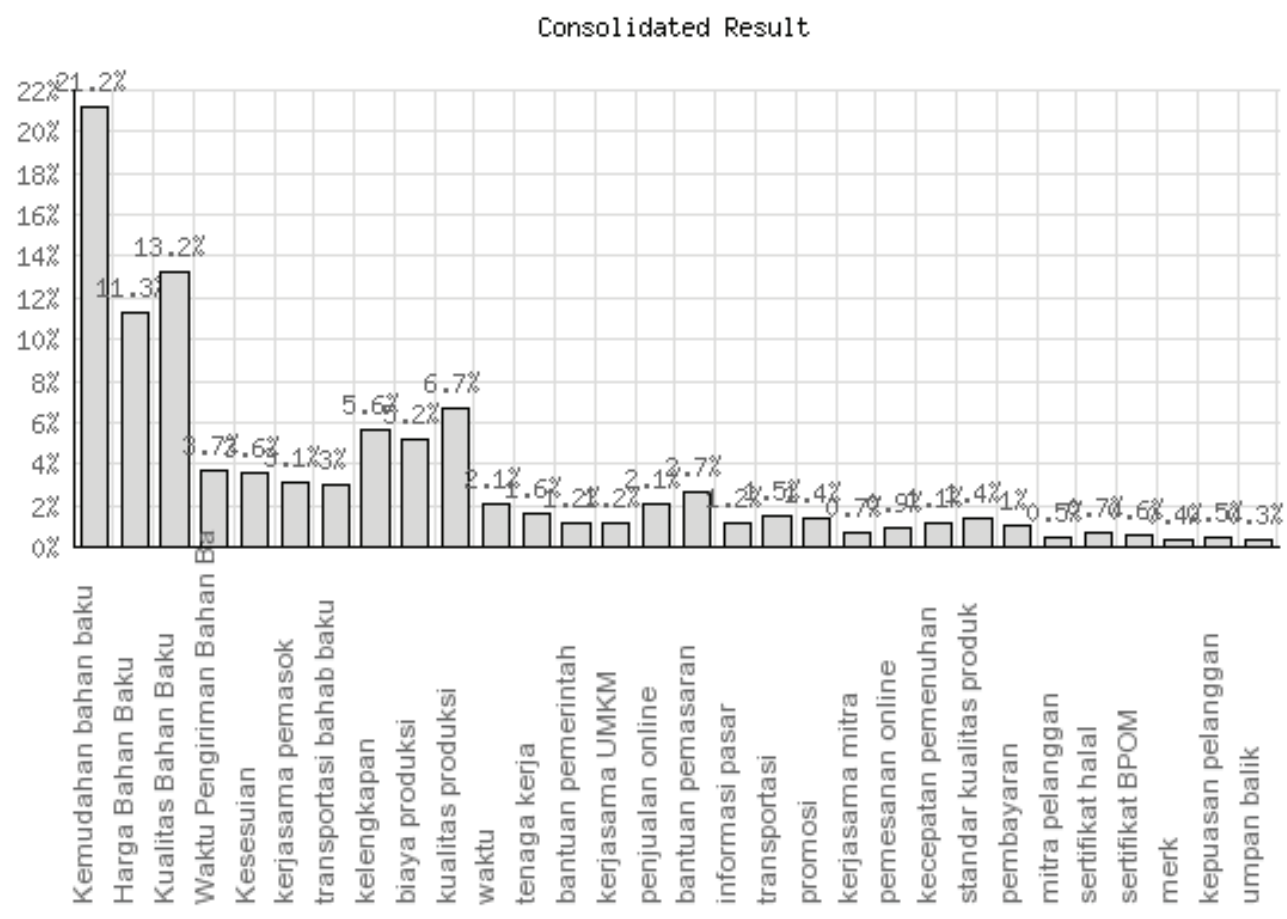

\section{Discussions}

\subsection{Raw material}

As small and medium-sized micro businesses in the West Tanjung Jabung Regency, which have seas producing fish and other marine products, the Supply Chain management model should be owned not as complicated as in most companies. However, this did not mean that the entire supply of raw materials can be fulfilled properly, because in reality there is a problem in the supply chain; raw material, both for fish processing craftsmen and coconut shell craftsmen. Adequate raw material inventory will guarantee the sustainability of the business and the quality of the goods that will reach consumers as end users. From the results of processing, the data above can be on a priority/ranking basis, the main priority was the availability of raw materials without intermediaries ( $59.1 \%)$, then followed by the production facilities factory $(23.7 \%)$, cooperation with distributors (9.7\%) and reaching consumers (7.4\%).

The raw material meant here was fish and shrimp as the main ingredient for processed fish food such as crackers, shrimp paste and coconut shells with thick skin to be processed into craft that was more resistant and easy to form. The supply chain of 
TABLE 7: Priority and ranking criteria.

\begin{tabular}{|l|l|c|c|}
\hline \multicolumn{2}{|l|}{ Category } & Priority & Rank \\
\hline 1 & Raw material & $59.1 \%$ & 1 \\
\hline 2 & Factory & $23.7 \%$ & 2 \\
\hline 3 & Distributor & $9.7 \%$ & 3 \\
\hline 4 & Customer & $7.4 \%$ & 4 \\
\hline
\end{tabular}

raw materials in this model was that entrepreneurs directly come to suppliers with the aim of getting cheap goods and can choose the quality as desired. The main reason for craftsmen to take this raw material directly was to be able to choose according to the desired criteria. Transportation costs and transportation of raw materials were also borne by employers so that this became a burden and increased production costs.

\subsection{Factory criteria}

In reporting this part, the factories or processing facilities owned are good enough, there is government assistance in the form of complete production equipment, while quality workforce was still a problem, so training was still needed in order to have more qualified resources to support optimal production processes. Collaboration between similar MSMEs was still low, this caused the availability of goods that was not guaranteed well and there were still MSMEs that accumulated unsold goods.

\subsection{Distributor criteria}

In this part, distributors still had low criteria for supporting the competitiveness of MSMEs. Business actors had not used online sales well so that the market was still limited. Broadcasting was still carried out individually-not yet wholly incorporated in the organization. There were cooperatives that float sales, while the markets served were still limited. With self-selling, the cost of transporting goods was quite high and promotion has not been maximized. Payment of goods sold through distributors was not yet smooth and always delinquent, and this caused the capital turnover to be hampered.

\subsection{Customer criteria}

In terms of consumer tastes, the quality standards of products from the packaging display still did not meet the required criteria, such as attractive packaging, resistant to weather changes, and easy to use. Halal certificates is as a reference for halal food, for 
those who did not have because of limited knowledge and a fairly time-consuming and high-cost process. Moreover, production standards still did not meet these criteria.

\section{Conclusions and Suggestions}

Based on the discussion of the study, conclusions can be drawn as follows. First, the availability of appropriate and quality raw materials was a major factor in the value supply chain to improve the competitiveness of MSMEs. Second, partnership with fishermen and coconut farmers was the best way carried out to increase the availability of raw materials. Third, sales of MSME products were still carried out individually by the craftsmen themselves, causing limited transportation costs and market coverage. Finally, payment systems from distributors would be obstacles because they were not paid in cash. Besides, the following suggestions are needed for further study, government, and employees such; 1) due to the supply chain model can contribute to improving the competitiveness of MSMEs, hence it can contribute directly to the economic and labor sectors, 2 support and assistance from the government will be needed to develop this model, and 3 ) the need for strict rules on distributors regarding payment systems will be useful for employers to implement this model.

\section{References}

[1] Abdullah, P., et al. (2002). Daya saing daerah: Konsep dan pengukurannya di Indonesia. Yogyakarta: BPFE.

[2] Bank Indonesia. (2016). Pemetaan dan strategi peningkatan daya saing UMKM dalam menghadapi masyarakat ekonomi ASEAN (MEA) 2015 dan pasca MEA 2025. Jakarta: Departemen Pengembangan UMKM Bank Indonesia.

[3] Badan Pusat Statistik Provinsi Jambi. (2016).

[4] Basher, V. (2010). Vendor Selection and Quota Allocation By Using Fuzzy Topics and Linear Programming. Master of Engineering in Production Engineering: University of Delhi India.

[5] Catrinu, M. A. and Nordgard, D. E. (2008). Reinvestment Strategy Making for Distribution Network. SINTEF: Energy Research.

[6] Fitriaty. (2017). Model integrasi sektor pariwisata dan ekonomi kreatif dalam meningkatkan daya saing daerah di Kabupaten Tanjung Jabung Barat.

[7] Irawati, I., Urufi, Z., Resoboen, R., et al. (2012). Pengukuran tingkat daya saing daerah, varibel infrastruktur dan sumber daya alam, serta variabel sumber daya mnusia di 
wilayah Sulawesi Tenggara. Jurnal J@TI Undip, vol. 7, no. 1.

[8] Holter, A. R., Grant, D. B., Ritchie, J., et al. (2008). A framework for purchasing transport services in SMEs. International Journal of Physical Distribution and Logistic Management, vol. 38, no. 1, pp. 21-38.

[9] Joerin, F., Riault, M., and Musy, A. (2000). Using GIS and outranking multicriteria analysis for land-use suitability assessment.

[10] Pariwisata, K. and Kreatif, E. (2015). Kekuatan baru Indonesia menuju 2025.

[11] Kementerian Luar Negeri. (2016). Masyarakat ASEAN: Geliat UMKM di Era MEA.

[12] Mahalakshmi, P., Panigrahi, A., Ravisankar, T., et al. (2014). Multi criteria decision making for identification of optimal location for aquaculture development. International Journal of Advances in Science Engineering and Technology, vol. 2, no. 3.

[13] Mathieson, A. and Wall, G. (1982). Tourism: Economic, Physical and Social Impacts. Longman: Harlow, UK.

[14] Omann. (2004). Multi-criteria decision aid as an approach for sustainable development analysis and implementation. Dissertation, zur Erlangung des akademischen Grades einer Doktorin der Sozial- und Wirtschaftswissenschaften an der KarlFranzens Universität Graz.

[15] The World Cafe Community Foundation. (2015). A quick referennce guide for hosting world cafe. Retrieved from: hhtp: www.theworrldcafe.com

[16] Thoo, A. C., Abu, B. A. H., Amran, R., et al. (2012). Adoption of supply chain management in SMEs. International Congress on Interdisciplinary Business and Social Science, vol. 65, pp. 614-619.

[17] Titik, A., et al. (2015). Pemetaan dan strategi peningkatan daya saing UMKM dalam menghadapi MEA 2015 dan Pasca-MEA 2025 (Working Paper). Jakarta: Bank Indonesia. 